\title{
Investigating customer satisfaction towards music website in Indonesia and India: a comparative study
}

\section{Reni Diah Kusumawati ${ }^{\star}$ and Teddy Oswari}

Faculty of Economic,

Gunadarma University,

Depok, Indonesia

Email: reni_dk@staff.gunadarma.ac.id

Email: toswari@staff.gunadarma.ac.id

*Corresponding author

\section{Tristyanti Yusnitasari}

Faculty of Computer Science and Information Technology,

Gunadarma University,

Depok, Indonesia

Email: tyusnita@staff.gunadarma.ac.id

\section{Himanshu Dutt}

Visiting Faculty, Jamia Millia Islamia (Central University),

New Delhi, India

Email: himanshudutt@gmail.com

\section{Vijay Kumar Shukla}

Faculty of Economic,

Army Institute of Management and Technology,

New Delhi, India

Email: v.vijayshukla.s@gmail.com

\begin{abstract}
The development of information technology has become new world, and an infinite business network. One proof of these technologies is internet, which is causing information technology to make a positive impact, and changed lifestyle into modern societies. It has created new types of business opportunities where business transactions are increasingly being made electronically. The growing popularity of such websites shows a rise in their demand. This research places an effort to understand the effect of service quality on customer satisfaction on music product websites with respondents from Indonesia and India, and compares are there any differences in consumer attitudes. It was observed that responsiveness, assurance, and empathy affect on customer satisfaction of music product website and tangibles, reliability and responsiveness have the same impact for both countries, but assurance, empathy and customer satisfaction differ. This is an important milestone in understanding customer's intention in buying music online in both countries.
\end{abstract}


Keywords: customer satisfaction; service quality; music product; website; Indonesia; India.

Reference to this paper should be made as follows: Kusumawati, R.D., Oswari, T., Yusnitasari, T., Dutt, H. and Shukla, V.K. (2020) 'Investigating customer satisfaction towards music website in Indonesia and India: a comparative study', Int. J. Digital Signals and Smart Systems, Vol. 4, Nos. 1/2/3, pp.17-39.

Biographical notes: Reni Diah Kusumawati has educational background in Management for Bachelor degree, Accounting Information System for Master degree, and $\mathrm{PhD}$ degree at Gunadarma University, Indonesia. She is a staff of secretariat at Gunadarma University. Her current research focuses on costumer behaviour and marketing. Besides that, she is interest with research about information system and trying to combine information system and economic sciences.

Teddy Oswari is registered as a lecturer since 2002 at Gunadarma University. $\mathrm{He}$ is active as a reviewer and have more than 90 scientific articles for national and international. He was takehold of PT, Carana Indonesia (holding company) as a President Commissioner, and as President Director of PT, Carana Lentera Prima on 2006-2009. He is also a Research Collaborator at Department of AMBD in Indonesia, University of Cumbria, UK. He also registered in a Financial Business Process team and Insurance Information System Auditor at PT, Asuransi Jiwasraya. He is a member of The Future Defence Leader from Defence Ministry of Republic of Indonesia, member of International Global Management Association (IGMA), Canada and supervision team of excellent university student, Qingdo-China.

Tristyanti Yusnitasari is a graduate of Information Technology Doctoral Program, Gunadarma University. She is the Head of Information System Laboratory, Gunadarma University. Her activities are developing some applications and instructor for some courses at Information System Laboratory, Gunadarma University. She has written some research papers published in national journals and attended some seminars and presented her papers. She has organised some seminars and workshops in area of information technology.

Himanshu Dutt is a Visiting Faculty at Jamia Millia Islamia, Central University at New Delhi, India. He has a PhD in Knowledge Management from Jamia Millia Islamia, Central University, New Delhi-India. His career mostly well in marketing, CRM, and customer experience areas. He is currently serving as head customer success (digital).

Vijay Kumar Shukla has educational background in Human Resource at Army Institute of Management and Technology, Greater Noida-India. His research topic is about customer behaviour, human resource, and marketing. He is also interested with research about technology and trying to combine with economic sciences.

This paper is a revised and expanded version of a paper entitled 'A comparison of service quality on customer satisfaction towards music product website in Indonesia and India' presented at International Conference on Sustainable Energy, Electronics \& Computing Systems (SEEMS-2018), Greater NoidaDelhi, India, 26-27 October 2018. 


\section{Introduction}

The development of technology and information, especially the internet has developed very rapidly. The internet technology has changed the lifestyle of primitive Indonesian society to modern society. With the development of information technology today, has created new types and business opportunities where business transactions are increasingly being made electronically (Gupta, 2014). One of the benefits of internet existence is as a media promotion of a product. A product that is online through the internet can bring huge profits to the entrepreneur because its products are known all over the world, and companies can utilise consumer online feedback to increase sales volume (Kumar and Pradhan, 2016).

The internet has become an integral part of modern society and economies around the world. This change has led to an unprecedented transformation in the world of business, communication, social interaction, research and education, governance, philanthropic activities and many other spheres of life (St. Amour, 2012). The internet is a medium used by business people not only to communicate but also to sell their products (Purity, 2014). The ease of using the internet as a medium to sell the product provides many benefits for a businessman such as wider market reach, ease of promotion, more efficient of cost and time. Companies that decide to sell their products online should pay attention to the services provided by both the website service and the employees who are tasked to provide services to online customers.

The number of internet users in India was estimated to be 481 million in December 2017, a growth off $11.34 \%$ over December 2016 estimated figures. The number of internet users is expected to reach 500 million by June 2018, according to a report 'Internet in India 2017'. The report also finds that an estimated 281 Million daily internet users, out of which 182.9 million or $62 \%$ access internet daily in the urban area, as compared to only 98 million users or $53 \%$, in rural India. Almost double the proportion of Rural Users access the internet less than once a month in rural India as compared to Urban India (Statista).

According to internet user survey data conducted by the Association of Internet Network Providers Indonesia (APJII), in 2017 from the total population of Indonesia as many as 262 million people there are 143.26 million people of Indonesia have been connected to the internet. This indicates an increase of $54.68 \%$ compared to the number of internet users in 2016 of $51.8 \%$. The increasing number of internet users in Indonesia has attracted various business ventures to sell their products through the internet by providing or creating online stores as part of e-commerce.

The music industry takes advantage of this opportunity to introduce and sell its music products both songs, video clips complete with the lyrics of the song through the internet. Changes in selling music products forced the music industry to create music websites that could attract customers. The ease with which the music website is offered and the completeness of the music products offered in a website, as well as the convenience of good service provided by a music website, will easily attract customers to visit the music website. The music industry should pay attention to the quality of service provided to customers and the good performance of employees to make customers feel satisfied and then loyal to the products offered, so it can increase the revenue of the music industry.

Income earned by the music industry is increasing, such as downloading songs by customers through music websites, ads contained in songs or video clips and, also by subscribing content made by the internet users (co-created content) when they search for 
music. Changes in how to promote a song have a positive impact on the music industry, as the broad reach in introducing a song can make the song globally known, and this change also benefits the music industry in reducing production costs because it no longer needs compact disk (CD) in selling songs.

Customer satisfaction can be influenced by the services provided by the employees and in this research is the service provided by the music product website where the customer can download the song through the music website. Services provided can be either an online chat facility with the employee of an online store or speed in providing responses when customers have difficulty in downloading songs. Other services such as providing recommendations for customers in choosing music products such as songs based on customer habits in listening to songs via the internet. These services will greatly assist customers in determining what music product or song they want to consume.

The purpose of this study is to measure customer satisfaction based on service quality on online music website in India and Indonesia. The quality of service in this study is measured by indicators of tangible, reliability, responsiveness, assurance, empathy, and to identify the relationship between service quality on online music sites of customer satisfaction in India and Indonesia partially and simultaneously.

\section{Literature review}

\subsection{Theory of planned behaviour}

The planned behavioural theory postulates three concepts that determine intent (Ajzen, 1991), that is

1 attitudes, to behaviours related to the evaluation of likes or dislikes or judgments of behaviour

2 subjective norms, in the form of pressure or the influence of the social environment that constitutes or does not shape behaviour

3 behavioural control, which simplifies the difficulty in shaping behaviour, with the assumption of reflection from past experiences by overcoming obstacles and obstacles.

Figure 1 Theory of planned behaviour

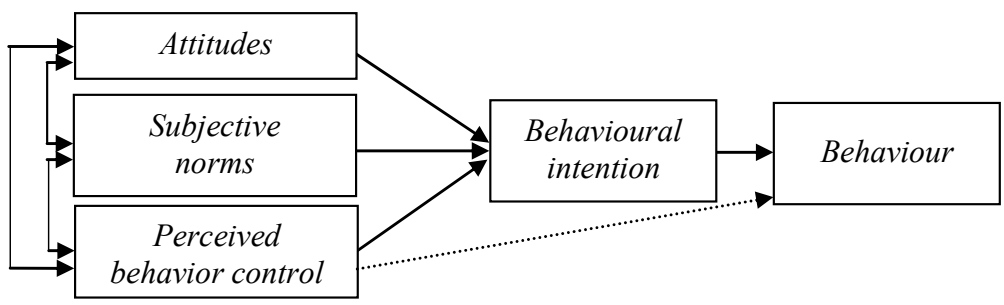

Source: Ajzen (1991)

Attitudes toward a behaviour are influenced by the belief that the behaviour will bring the desired or unwanted results. Beliefs about what behaviours are normative (expected by others) and the motivations to act on the expectations of the norm form the subjective 
norm in the individual. Behaviour control is determined by past experience and individual estimates of how difficult or easy it is to perform the behaviour. This control has a very important role when a person's confidence is in a weak condition. The planned behavioural model is shown in Figure 1.

\subsection{Customer satisfaction}

Customer satisfaction is an evaluation or cognitive assessment of whether the performance of products or services is relatively good or not. The problem of satisfaction is an individual matter that is subjective because one's satisfaction is not necessarily the same as the satisfaction felt by others. Although the services provided have the same characteristics or service quality. Therefore, this satisfaction is very difficult to measure quantitatively. Customer satisfaction is the result perceived by buyers who experience the performance of a company in the form of goods or services in accordance with his expectations (Kotler and Armstrong, 2008). Customers are satisfied if their expectations are met and feel very happy if their expectations are exceeded.

Customer satisfaction can only be achieved by providing quality services to its customers. In meeting customer expectations, companies need to know the level of customer expectations. High customer satisfaction will increase customer loyalty. Good service is often assessed by customers directly from employees as a person who serves or is also called as a service producer, therefore it takes an effort to improve the quality of service systems provided in order to meet the desires and increase customer satisfaction (Ali and Sankaran, 2010).

The quality of service is an important thing that must be considered by the company in order to achieve customer satisfaction. Quality of service has a close relationship with customer satisfaction. Quality provides an impetus to customers to establish strong relationships with companies. In the long run, this bond allows the company to understand carefully the expectations of customers and their needs. Thus, the company can increase customer satisfaction and in turn, such satisfaction can create loyalty or customer loyalty.

Measuring customer satisfaction is important in providing better, more efficient and more effective service. If the customer is not satisfied with a service provider, then the service can be deemed as ineffective and inefficient. In perfect competition conditions, where customers are able to choose between multiple service alternatives and have sufficient information, customer satisfaction is a key determinant of service demand and supplier operational or functionalities.

\subsection{Service quality}

Service is essentially an activity or benefit offered by a party to another party and is essentially intangible and does not result in ownership of something, its production process may also not be associated with a physical product. Meanwhile, service is a product that is intangible, lasted briefly and can be felt or experienced (Lovelock and Wirtz, 2011). This means that the service is a product that has no form so that no form can be owned, and lasts for a moment or not durable, but can be experienced and can be felt by the recipient of the service.

Quality of service becomes a must that must be done company to survive and still get customer trust. Patterns of consumption and lifestyles require customers to provide 
quality services. The company's success in providing quality services can be determined by the service quality approach (Zeithaml et al., 2009). Quality of service centred on a reality that is determined by the customer. The interaction of service strategy, service system and human resource and customer will greatly determine the success of the company management. Therefore, it is necessary to implement strategies to establish the best quality of service.

Quality of service is influenced by two main factors, that is expected service and perceived service (Zeithaml et al., 2009). If the perceived service is in accordance with the expected, then the quality of service is perceived as good and satisfactory. If the service received exceeds the customer's expectations, then the quality of service is perceived as the ideal quality. The famous method is SERVQUAL which is an empirically derived method that can be used by service organisations to improve service quality. This model asserts that performance on an attribute (attribute performance) increases greater than expectations for the attributes concerned, then the quality of service will also increase.

\subsection{Service quality attributes and measuring quality perceptions}

Certain services are more industrialised and transactional-based, e.g. fast food, ticket sales, and airline check-in desks. Other service encounters feature more unpredictability, and hence opportunities for customisation through situational sensitivity (Grönroos, 2005). It was found that if the service employees, through their experience and observations of encounters, were to compile a basic list of significant service attributes they would, in turn, to be able to formulate a simple measurement system that would emulate the process control system of manufacturing. The study evidenced a two-step configuration of attributes-should values and could values - the former being values without which the latter could not effectively operate (Grönroos, 2005).

Service employees privately sampled their own performance, using a preset scoring system. Findings indicated that using such simple measuring techniques actually enhanced performance where the rate of continuous improvement was known. Where performance was measured and the rate of continuous improvement was not known, performance degraded over time.

There has been a range of studies of service quality conducted in many countries. From them, various lists of attributes of factors of good quality can be collated. As was mentioned earlier in the context of the SERVQUAL determinants, such lists are useful as starting points for managers who want to develop an appropriate list of attributes of features that describe a given service. However, in order to make such lists of determinants or factors of good service quality useful for managerial purposes, they have to be short, yet still provide a comprehensive list of aspects of good quality.

\subsection{Conceptual framework}

In the era of globalisation, every company faces stiff competition. Increased intensity of competition and many competitors require companies to always pay attention to the needs and desires of consumers and trying to meet consumer expectations by providing a more satisfactory service than competitors to provide satisfaction to consumers.

Thus, only qualified firms can compete and survive in the market. Quality has a close relationship between customer satisfaction and employee performance. Quality provides 
incentives for customers to forge strong relationships with dodgy companies. The company has a goal to keep customers happy where quality has a direct impact on product performance as well as customer decisions.

Employee performance in terms of services is also important for the company to consider because employees in the service field have a direct relationship with customers. Thus, companies can increase customer satisfaction in which companies maximise the pleasant customer experience and minimise an unpleasant customer experience. The product or service is a representation of the company directly perceived by the customer. So, for customers to feel positive relationships and emotional ties, companies need to focus on improving the customer's positive experience along with the products or services the company offers. The positive experience of consumers will increase customer satisfaction of products or services offered by the company.

A conceptual framework has been created. The research findings show that the dimension of service quality and employee performance have an influence on customer satisfaction. Consumer satisfaction fully mediates the relationship between quality of service and employee performance. Furthermore, customer satisfaction is positively correlated with service quality and employee performance. The diagram below shows the relationship between attitudes and employee productivity.

Figure 2 Research model (see online version for colours)

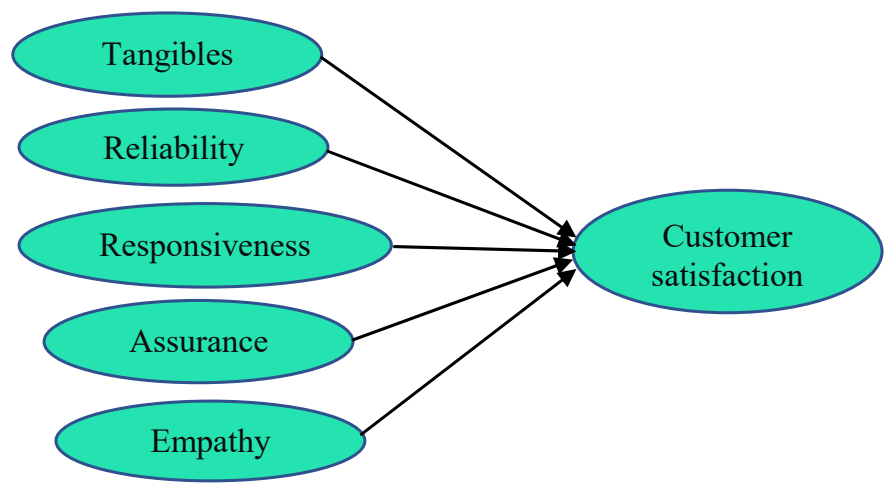

Concerning the conceptual framework, there are many researchers studying the relationship between service quality, employee performance, and customer satisfaction in various fields. The conceptual framework is positive and negative compatible with service quality, and employee performance. A positive attitude of service quality and employee performance is positively related to customer satisfaction, while service quality and negative employee performance are negatively related to customer satisfaction.

Based on the review of the research model used, the research hypothesis can be formulated as follows:

H1 Variable of tangibles affect on customer satisfaction partially.

H2 Variable of reliability affect on customer satisfaction partially.

H3 Variable of responsiveness affect on customer satisfaction partially.

H4 Variable of assurance affect on customer satisfaction partially.

H5 Variable of empathy affect on customer satisfaction partially. 
H6 Variable of tangibles, reliability, responsiveness, assurance, and empathy affect on customer satisfaction simultaneously.

This study also conducted a comparison of research results of service quality on consumer satisfaction online music products from India and Indonesia.

\section{Research methodology}

This research is a consumer behaviour research that is generally multidimensional research, meaning that the observed practical phenomenon can be expressed in various dimensions or indicators. The process of drawing conclusions in management research is generally multidimensional and tiered, therefore required a model as well as an analytical tool capable of accommodating this multi-dimensional research and can be used as a standard assessment.

The method used in this research is the descriptive method. The descriptive method aims to give an idea of a society or a particular group of people or a picture of a symptom or relationship between two or more symptoms. Descriptive research is the accumulation of basic data in a descriptive way solely unnecessary searching or explaining interconnected, testing hypotheses, making predictions or obtaining meaning and implications. Although research aimed at finding such matters may include descriptive methods (Arikunto, 2010). This research is quantitative, ie research that solving the problem with based on the numbers derived from the questionnaire or can be drawn conclusions and given suggestions.

Stages performed in scientific research are referring to the accuracy of methodology and in accordance with the object under study, the suitability of nature and diversity of the research must be calculated appropriately, in order to achieve the objectives through testing a series of predictions by using certain analytical tools (Hadi, 1986; Sekaran and Bougie, 2016; Cooper and Emory, 1996).

To achieve the aim and objectives, the research used quantitative data from the survey (questionnaire-based), and Likert scale 1-5 is used as a measurement. The populations in this study are the consumer of music product from Indonesia and India, using 106 of respondents as a sample from Indonesia and India who have used the music website. Hypothesis used in this research is multiple regression analysis techniques and different test.

The grant theory in this study is the theory of planned behavioural (Ajzen, 1991), who postulated three concepts that determine, that are attitudes, norms, and behaviour control, and also use a model of consumer behaviour (Kotler, 1997), which explains behaviour of consumers. The variables measured in the research questionnaire include

1 tangibles

2 reliability

3 responsiveness

4 assurance

5 empathy

6 customer satisfaction. 
The questionnaire in this study refers to the previous research (Gupta, 2014; Ali and Sankaran, 2010; Archakova, 2013; Utami, 2013).

Data of demographic variable in this research is to know the identity of the respondents, consisting of gender variable, the attribute of respondent's gender with a nominal measurement scale. Age variable with respondent of age attribute with ordinal measurement scale. Variable educational background with the highest attribute of education of respondent with ordinal measurement scale. Job variables with job attributes of respondents with ordinal measurement scale. Variable income with attribute the amount of respondent's income by ordinal measurement scale. Domicile variable with the attribute of residence location of respondent use nominal scale.

\section{Result and discussion}

\subsection{Demographic characteristic}

This study aims to examine the effect of service quality on customer satisfaction with respondents are from Indonesia and India with 106 respondents from each country, then perform a different test to determine there are whether or not differences in consumer satisfaction. Six variable's questions have been used for collecting general information from the respondents. The general information includes occupation, gender, age, marital status, department, designation and experience period in the company.

Figure 3 Respondents' gender (see online version for colours)
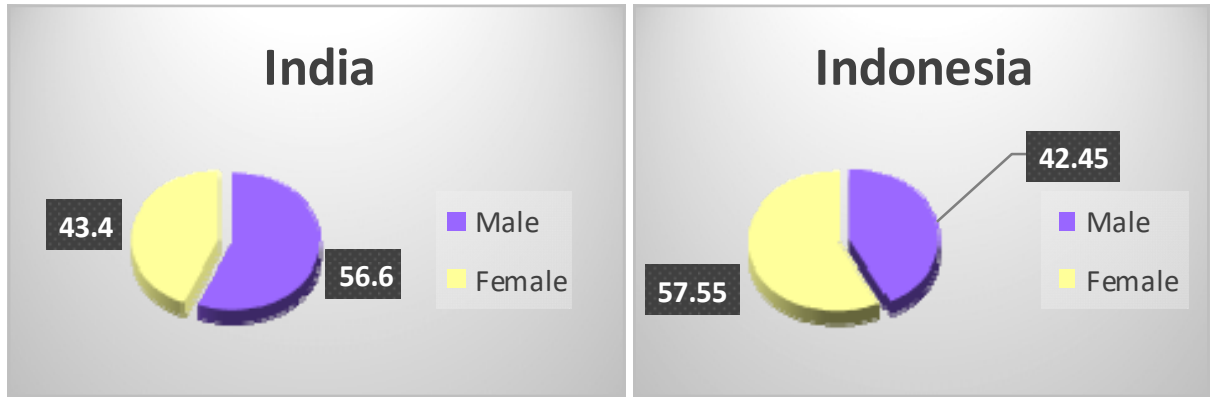

Respondents in India representing $56.60 \%$ were males while $43.40 \%$ were females, respondents in Indonesia representing $42.45 \%$ were males while $57.55 \%$ were females. Figure 3 shows the visual impression of male and female respondents that were considered in the research study.

Age distribution of respondents shows that most respondents are in the age category of $21-25$ years with $73.58 \%$ are respondents from India and $52.83 \%$ are respondents from Indonesia. Figure 4 depicts the age group of respondents.

According to the given data, there are difference respondents from India and Indonesia, most of the respondents from India are from postgraduate and most respondents from Indonesia are from secondary education. Figure 5 shows the visual impression of the educational background respondents in the research study. 
Figure 4 Respondents' age (see online version for colours)
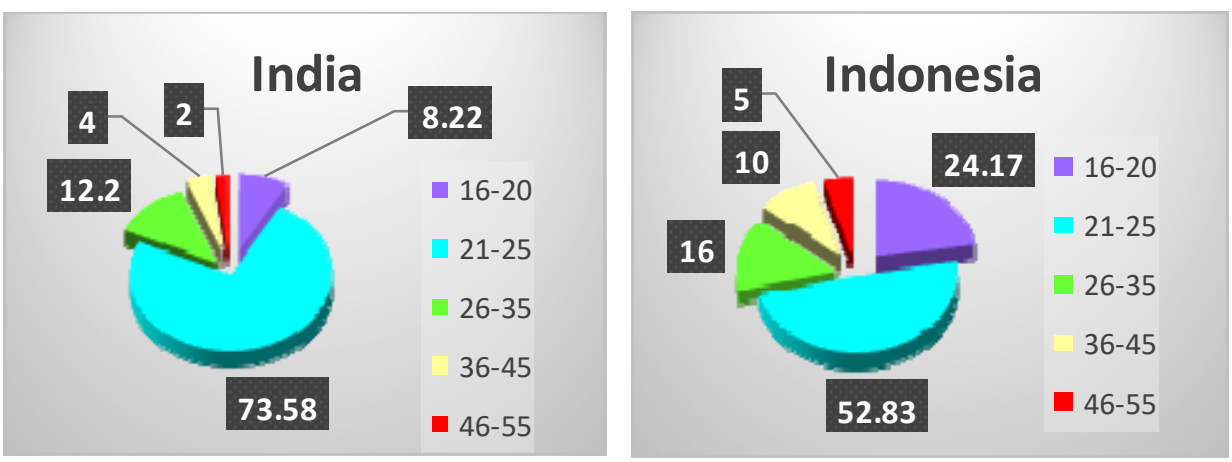

Figure 5 Respondents' educational background (see online version for colours)

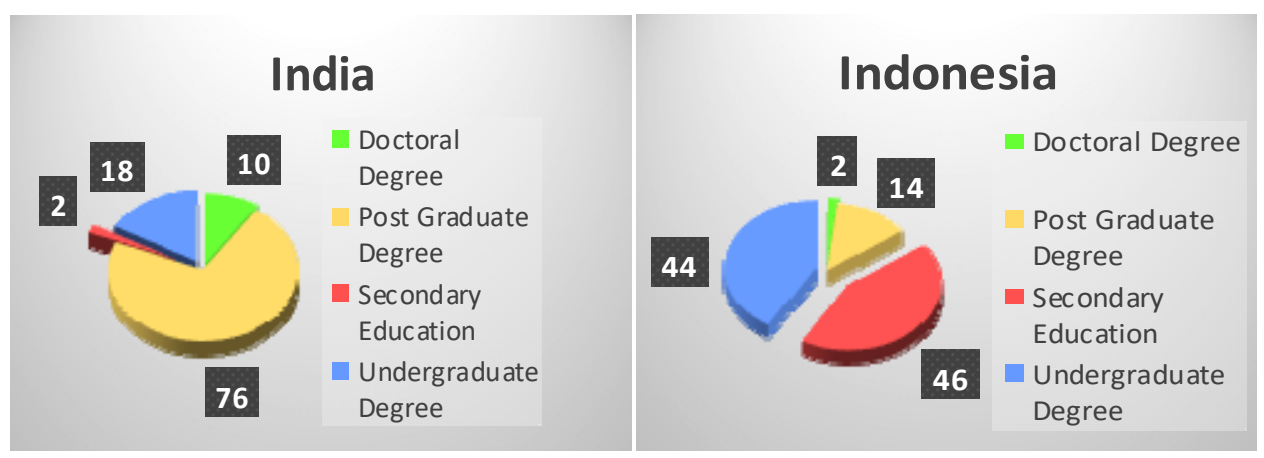

Link of online music distribution of respondents shows that there is one link named Spotify which is used by the consumer to listen to the music both respondents from India and Indonesia. Figure 6 shows the favourite link of online music of respondents.

Figure 6 Respondents' favourite link of online music (see online version for colours)
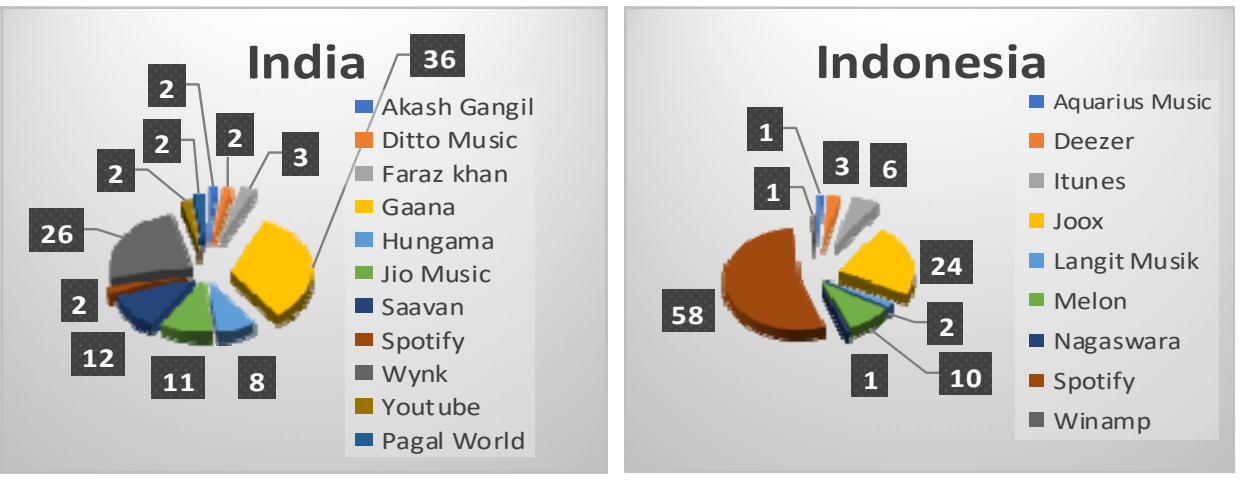


\subsection{Validity and reliability test}

The validity test has been performed on the items used in the questionnaire, and the results of the validity test on service quality, and customer satisfaction show significant value $(p<0.05)$ and greater than the $r$ table value of 0.197 , which means that all the question items in questionnaires declared valid and can be used in research. The reliability test shows a value $>0.60$ which means that the data used in the questionnaire can be trusted.

\subsection{Analysis and research result}

Multiple linear regression analysis is a linear relationship between two or more independent variables (X1, X2, X3, X4, X5) with dependent variable (Y), whether each of the independent variables is positively or negatively associated and for predict the value of the dependent variable whether the value of the independent variable is experienced increase or decrease. Multiple linear regression tests were performed for knowing the effect between tangibles, reliability, responsiveness, assurance, empathy on customer satisfaction.

Table 1 Multiple linear test results - India

\begin{tabular}{|c|c|c|c|c|c|c|}
\hline \multicolumn{7}{|c|}{ Coefficients $^{\mathrm{a}}$} \\
\hline \multirow{2}{*}{\multicolumn{2}{|c|}{ Model }} & \multicolumn{2}{|c|}{$\begin{array}{l}\text { Unstandardised } \\
\text { coefficients }\end{array}$} & \multirow{3}{*}{$\begin{array}{c}\text { Standardised } \\
\text { coefficients }\end{array}$} & \multirow{3}{*}{$\begin{array}{c}t \\
1.167\end{array}$} & \multirow{3}{*}{$\begin{array}{l}\text { Sig. } \\
.246\end{array}$} \\
\hline & & \multirow{2}{*}{$\frac{B}{1.974}$} & \multirow{2}{*}{$\frac{\text { Std. error }}{1.691}$} & & & \\
\hline 1 & (Constant) & & & & & \\
\hline & Tangibles & .003 & .127 & .002 & .025 & .980 \\
\hline & Reliability & .018 & .140 & .011 & .126 & .900 \\
\hline & Responsiveness & .303 & .112 & .232 & 2.706 & .008 \\
\hline & Assurance & .703 & .098 & .519 & 7.213 & .000 \\
\hline & Empathy & .324 & .108 & .230 & 2.998 & .003 \\
\hline
\end{tabular}

Note: a. Dependent variable: customer satisfaction

Table 2 Multiple linear test results - Indonesia

\begin{tabular}{|c|c|c|c|c|c|c|}
\hline \multicolumn{7}{|c|}{ Coefficients $^{\mathrm{a}}$} \\
\hline \multirow{2}{*}{\multicolumn{2}{|c|}{ Model }} & \multicolumn{2}{|c|}{$\begin{array}{l}\text { Unstandardised } \\
\text { coefficients }\end{array}$} & \multirow{3}{*}{$\begin{array}{c}\text { Standardised } \\
\text { coefficients }\end{array}$} & \multirow{3}{*}{$\begin{array}{c}t \\
2.809\end{array}$} & \multirow{3}{*}{$\begin{array}{l}\text { Sig. } \\
.006\end{array}$} \\
\hline & & \multirow{2}{*}{$\frac{B}{4.431}$} & \multirow{2}{*}{$\begin{array}{c}\text { Std. error } \\
1.577\end{array}$} & & & \\
\hline 1 & (Constant) & & & & & \\
\hline & Tangibles & .161 & .192 & .098 & .840 & .403 \\
\hline & Reliability & -.065 & .187 & -.049 & -.350 & .727 \\
\hline & Responsiveness & .324 & .126 & .251 & 2.578 & .011 \\
\hline & Assurance & .428 & .121 & .316 & 3.544 & .001 \\
\hline & Empathy & .395 & .106 & .314 & 3.727 & .000 \\
\hline
\end{tabular}

Note: ${ }^{a}$ Dependent variable: customer satisfaction 
Based on Table 1 can be found model of regression equation by seeing the value of $B$ in the unstandardised coefficients column as follows:

$$
Y=1.974+3 X_{1}+18 X_{2}+303 X_{3}+703 X_{4}+324 X_{5}
$$

Based on Table 2 can be found model of regression equation by seeing the value of $B$ in the unstandardised coefficients column as follows:

$$
Y=4.431+161 X_{1}-65 X_{2}+324 X_{3}+428 X_{4}+395 X_{5}
$$

Information:

$Y \quad$ customer satisfaction

$X_{1} \quad$ tangibles

$X_{2}$ reliability

$X_{3}$ responsiveness

$X_{4}$ assurance

$X_{5}$ empathy.

\subsection{Multiple correlation analysis}

Multiple correlation analysis is used to find out the relationship between two or more independent variables $\left(\mathrm{X}_{1}, \mathrm{X}_{2}, \ldots \mathrm{X}_{\mathrm{n}}\right)$ to the dependent variable $(\mathrm{Y})$ simultaneously. This coefficient shows how big the relationship is between tangibles, reliability, responsiveness, assurance, and empathy as Independent variables (X) simultaneously on customer satisfaction as the Dependent variable (Y). Guidance to provide interpretation of the correlation coefficient as follows:

0

: no correlation between two variables

$>0-0.25$ : very weak correlation

$>0.25-0.5$ : sufficient correlation

$>0.5-0.75$ : strong correlation

$>0.75-0.99$ : very strong correlation

1 : perfect correlation.

Table 3 Correlation variables X and Y - India

\begin{tabular}{lcccc}
\hline \multicolumn{4}{c}{ Model summary $^{\mathrm{b}}$} \\
\hline Model & $R$ & $R$ square & Adjusted $R$ square & Std. error of the estimate \\
\hline 1 & $.814^{\mathrm{a}}$ & .662 & .645 & 2.543 \\
\hline
\end{tabular}

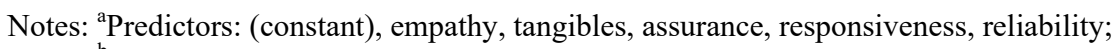

${ }^{\mathrm{b}}$ Dependent variable: customer satisfaction

From Table 3 note that the result of correlation analysis $\mathrm{R}$ is 0.814 . Since the value of multiple correlations is between $>0.75$ to 0.99 then it can be concluded that there is a 
very strong relationship between tangibles $\left(\mathrm{X}_{1}\right)$, Reliability $\left(\mathrm{X}_{2}\right)$, Responsiveness $\left(\mathrm{X}_{3}\right)$, Assurance $\left(\mathrm{X}_{4}\right)$, Empathy $\left(\mathrm{X}_{5}\right)$, on Customer Satisfaction $(\mathrm{Y})$.

The coefficient of Determination or Test of $\mathrm{R}^{2}$ is used to know the percentage contribution of independent variables $\left(\mathrm{X}_{1}, \mathrm{X}_{2}, \mathrm{X}_{3}, \mathrm{X}_{4}, \mathrm{X}_{5}\right)$ to variables Dependent $(\mathrm{Y})$. If $\mathrm{R}^{2}$ equals 0 (zero), then there is no percentage at all Contribution of influence given variable independent of a variable dependent, otherwise, if $\mathrm{R}^{2}$ equals 1 , then the percentage of donation effect given is perfect or the variation of the independent variable used in the model describes $100 \%$ variation of the dependent variable.

From Table 3 obtained R-Square or coefficient of determination is 0.662 . For multiple linear regression with independent variables more than two, you should use Rsquare that has been adjusted or Adjusted R-square. Adjusted R-square Number is 0.645 or $64.5 \%$. This shows that the percentage donations influence of the independent variables of tangibles, reliability, responsiveness, assurance, and empathy on the dependent variable (customer satisfaction) of 0.645 or $64.5 \%$, and the remaining $35.5 \%$ explained by other variables besides tangibles, reliability, responsiveness, assurance, and empathy.

The standard error of the estimate is a measure the number of regression model errors in predicting the value of $\mathrm{Y}$. The result of regression value is 2.543 , this means the number of errors in the prediction of productivity.

Table 4 Correlation variables $\mathrm{X}$ and $\mathrm{Y}$ - Indonesia

\begin{tabular}{lcccc}
\hline \multicolumn{5}{c}{ Model summary $^{\mathrm{b}}$} \\
\hline Model & $R$ & $R$ square & Adjusted $R$ Square $^{\text {Std. error of the estimate }}$ \\
\hline 1 & $.775^{\mathrm{a}}$ & .601 & .581 & 2.646 \\
\hline
\end{tabular}

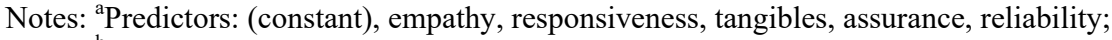

${ }^{b}$ Dependent variable: customer satisfaction

From Table 4 note that the result of correlation analysis $\mathrm{R}$ is 0.775 . Since the value of multiple correlations is between $>0.75$ to 0.99 then it can be concluded that there is a very strong relationship between tangibles $\left(\mathrm{X}_{1}\right)$, Reliability $\left(\mathrm{X}_{2}\right)$, Responsiveness $\left(\mathrm{X}_{3}\right)$, Assurance $\left(\mathrm{X}_{4}\right)$, Empathy $\left(\mathrm{X}_{5}\right)$, on Customer Satisfaction $(\mathrm{Y})$.

From Table 4 obtained R-Square or coefficient of determination is 0.601 . For multiple linear regression with independent variables more than two, you should use R-square that has been adjusted or Adjusted R-square (Priyanto, 2010). Adjusted $\mathrm{R}$-square number is 0.581 or $58.1 \%$. This shows that the percentage donations influence of the independent variable of tangibles, reliability, responsiveness, assurance, and empathy on the dependent variable (customer satisfaction) of 0.581 or $58.1 \%$, and the remaining $41.9 \%$ explained by other variables besides tangibles, reliability, responsiveness, assurance, and empathy.

The standard error of the estimate is a measure the number of regression model errors in predicting the value of $\mathrm{Y}$. The result of regression value is 2.646 this means the number of errors in the prediction of productivity.

\subsection{Partial test with t-test}

The t-test is used to determine whether in the variable regression model Independent $\left(\mathrm{X}_{1}\right.$, $\mathrm{X}_{2}, \mathrm{X}_{3}, \mathrm{X}_{4}, \mathrm{X}_{5}, \mathrm{X}_{6}$ ) partially significant effect on Dependent variable (Y). 
Table 5 Regression result $-\mathrm{t}$ test - India

\begin{tabular}{|c|c|c|c|c|c|c|}
\hline \multicolumn{7}{|c|}{ Coefficients $^{\mathrm{a}}$} \\
\hline \multirow{2}{*}{\multicolumn{2}{|c|}{ Model }} & \multicolumn{2}{|c|}{$\begin{array}{c}\text { Unstandardised } \\
\text { coefficients }\end{array}$} & \multirow{3}{*}{$\begin{array}{c}\begin{array}{c}\text { Standardised } \\
\text { coefficients }\end{array} \\
\text { Beta }\end{array}$} & \multirow[t]{2}{*}{$t$} & \multirow[t]{2}{*}{ Sig. } \\
\hline & & $B$ & Std. error & & & \\
\hline \multirow[t]{6}{*}{1} & (Constant) & 1.974 & 1.691 & & 1.167 & .246 \\
\hline & Tangibles & .003 & .127 & .002 & .025 & .980 \\
\hline & Reliability & .018 & .140 & .011 & .126 & .900 \\
\hline & Responsiveness & .303 & .112 & .232 & 2.706 & .008 \\
\hline & Assurance & .703 & .098 & .519 & 7.213 & .000 \\
\hline & Empathy & .324 & .108 & .230 & 2.998 & .003 \\
\hline
\end{tabular}

Note: ${ }^{a}$ Dependent variable: customer satisfaction

Analysis of coefficients table to find out the influence of independent variables partially to dependent variable is which has the greatest influence on customer satisfaction is assurance, then sequentially followed by empathy, responsiveness, reliability, and tangibles.

Table 6 Regression result $-\mathrm{t}$ test - Indonesia

\begin{tabular}{|c|c|c|c|c|c|c|}
\hline \multicolumn{7}{|c|}{ Coefficients $^{\mathrm{a}}$} \\
\hline \multirow{2}{*}{\multicolumn{2}{|c|}{ Model }} & \multicolumn{2}{|c|}{$\begin{array}{c}\text { Unstandardised } \\
\text { coefficients }\end{array}$} & \multirow{2}{*}{$\begin{array}{c}\begin{array}{c}\text { Standardised } \\
\text { coefficients }\end{array} \\
\text { Beta } \\
\end{array}$} & \multirow[t]{2}{*}{$t$} & \multirow{2}{*}{ Sig. } \\
\hline & & $B$ & Std. error & & & \\
\hline \multirow[t]{6}{*}{1} & (Constant) & 4.431 & 1.577 & & 2.809 & .006 \\
\hline & Tangibles & .161 & .192 & .098 & .840 & .403 \\
\hline & Reliability & -.065 & .187 & -.049 & -.350 & .727 \\
\hline & Responsiveness & .324 & .126 & .251 & 2.578 & .011 \\
\hline & Assurance & .428 & .121 & .316 & 3.544 & .001 \\
\hline & Empathy & .395 & .106 & .314 & 3.727 & .000 \\
\hline
\end{tabular}

Note: ${ }^{a}$ Dependent variable: customer satisfaction

Analysis of coefficients table to find out the influence of independent variables partially to dependent variable is which has the greatest influence on customer satisfaction is empathy, then sequentially followed by the assurance, responsiveness, tangibles, and reliability.

\subsection{Simultaneous test with F-test/Anova}

Anova test is used to determine whether there is influence together (simultaneously) independent variables to the dependent variable, by comparing between $\mathrm{F}_{\text {count }}$ with $\mathrm{F}_{\text {table }}$ at the level $\alpha=5 \%$. Here is an F / Anova test table that is processed using SPSS statistical tool.

Based on the output Table 7 , it can be stated Sig f $0.000<0.05$. In conclusion, tangibles, reliability, responsiveness, assurance, and empathy simultaneously affect on 
customer satisfaction. Based on results on Table 7, can be proved hypothesis that has been formulated.

Table 7 Simultaneous test with F-test/ANOVA - India

\begin{tabular}{llccccc}
\hline \multicolumn{7}{c}{ ANOVA $^{\text {a }}$} \\
\hline Model & Sum of squares & $d f$ & Mean square & $F$ & Sig. \\
\hline 1 & Regression & $1,265.532$ & 5 & 253.106 & 39.145 & $.000^{\mathrm{b}}$ \\
& Residual & 646.591 & 100 & 6.466 & & \\
& Total & $1,912.123$ & 105 & & & \\
\hline
\end{tabular}

Notes: a Dependent variable: customer satisfaction;

${ }^{\mathrm{b}}$ Predictors: (constant), empathy, tangibles, assurance, responsiveness, reliability

Table 8 Simultaneous test with F-test/ANOVA - Indonesia

\begin{tabular}{llccccc}
\hline \multicolumn{7}{c}{ ANOVA $^{\mathrm{a}}$} \\
\hline \multicolumn{1}{l}{ Model } & Sum of squares & $d f$ & Mean square & $F$ & Sig. \\
\hline 1 & Regression & $1,053.053$ & 5 & 210.611 & 30.072 & $.000^{\mathrm{b}}$ \\
& Residual & 700.353 & 100 & 7.004 & & \\
& Total & $1,753.406$ & 105 & & & \\
\hline
\end{tabular}

Notes: ${ }^{\mathrm{a} D e p e n d e n t ~ v a r i a b l e: ~ c u s t o m e r ~ s a t i s f a c t i o n ; ~}$

${ }^{\mathrm{b}}$ Predictors: (constant), empathy, responsiveness, tangibles, assurance, reliability

Based on the output of Table 8 , it can be stated Sig f $0.000<0.05$. In conclusion, tangibles, reliability, responsiveness, assurance, and empathy simultaneously affect on customer satisfaction. So, based on the results in Table 4.20, can be proved hypothesis that has been formulated.

\subsection{Independent sample t-test}

The independent samples $t$-test compares the means of two independent groups in order to determine whether there is statistical evidence that the associated population means are significantly different. The independent samples $t$-test is a parametric test.

The null hypothesis $\left(H_{0}\right)$ and the alternative hypothesis $\left(H_{1}\right)$ of the independent samples $t$-test can be expressed in two different but equivalent ways:

$H_{0}: \mu_{1}=\mu_{2}$ (the two populations mean are equal)

$H_{1}: \mu_{1} \neq \mu_{2}$ (the two populations mean are not equal)

OR

$H_{0}: \mu_{1}-\mu_{2}=0$ (the difference between the two populations means is equal to 0 )

$H_{1}: \mu_{1}-\mu_{2} \neq 0$ (the difference between the two populations means is not 0 )

where $\mu_{1}$ and $\mu_{2}$ are the populations means for group 1 and group 2, respectively. Notice that the second set of hypotheses can be derived from the first set by simply subtracting $\mu_{2}$ from both sides of the equation. 
Table 9 Independent samples T test result - tangibles

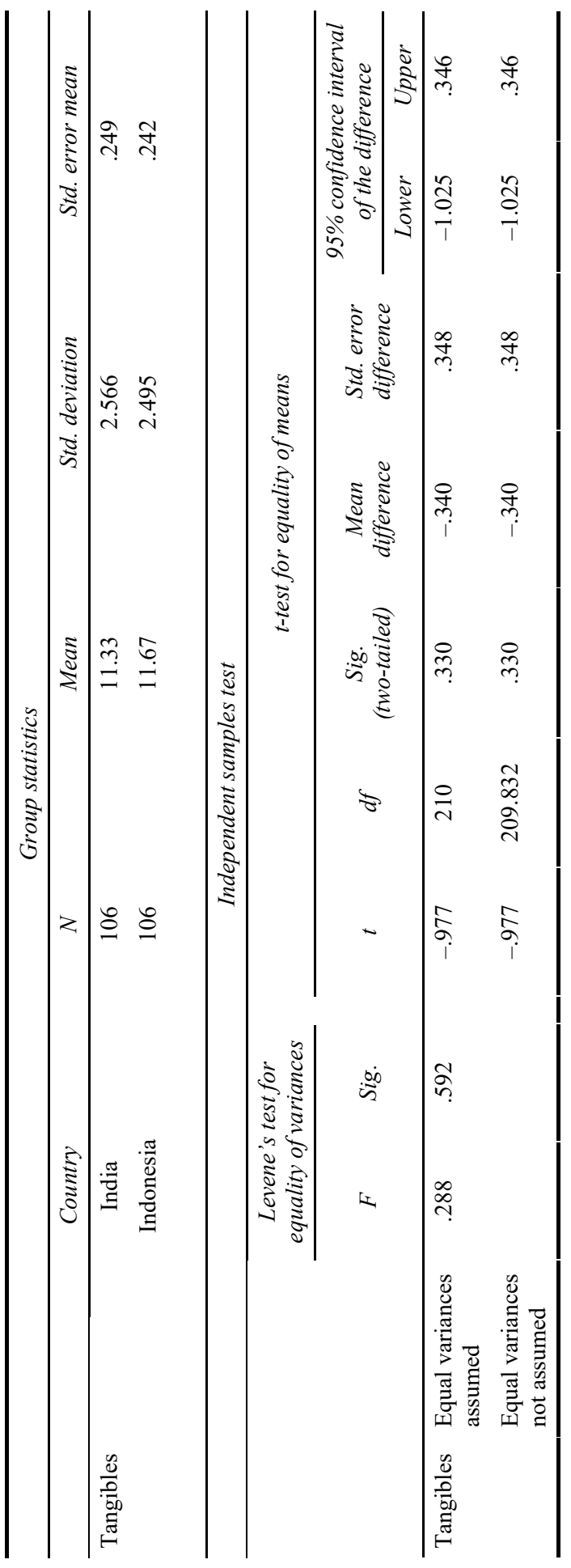


Table 10 Independent samples t-test result - reliability

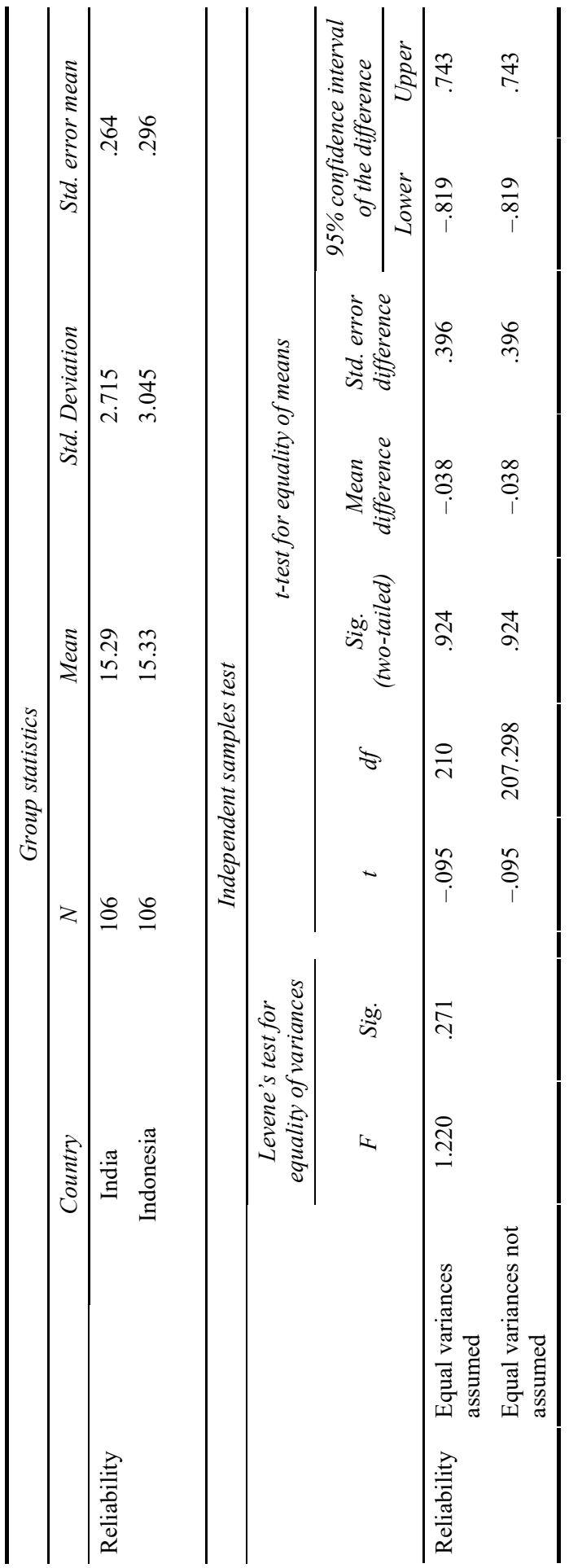


Table 11 Independent samples T test result - responsiveness

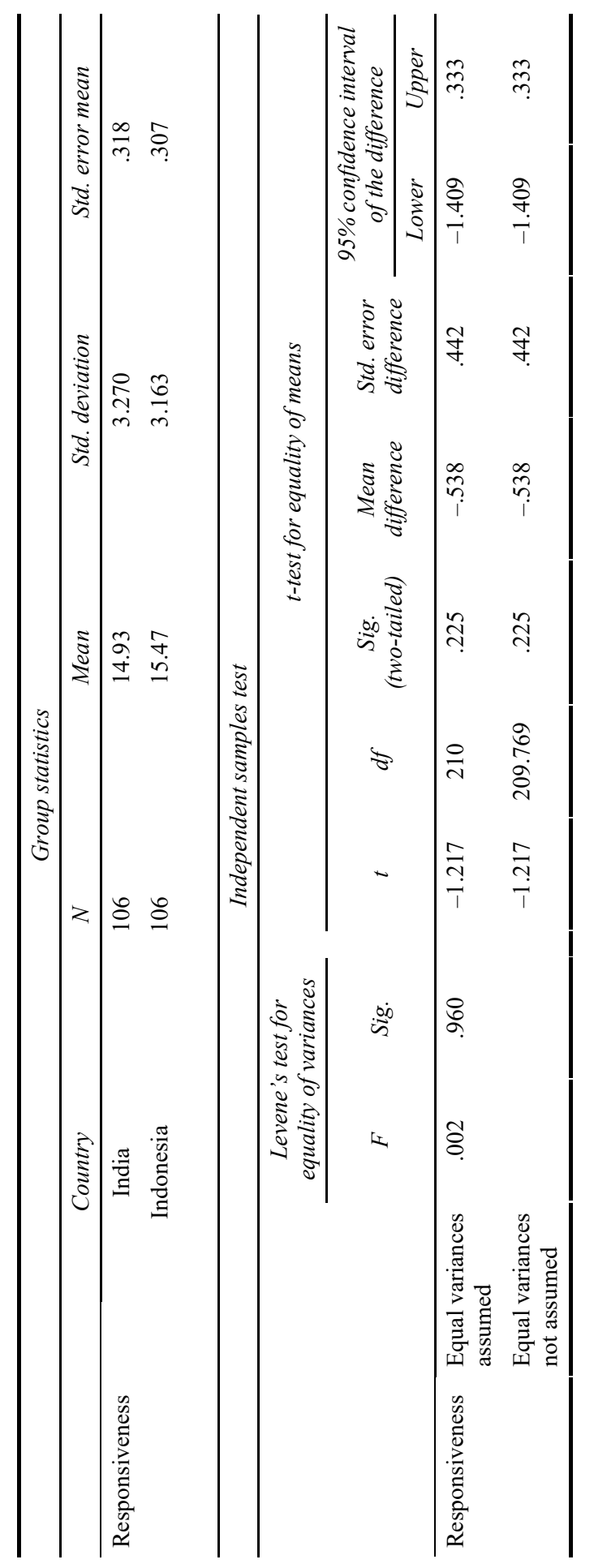


Table 12 Independent samples $\mathrm{T}$ test result - assurance

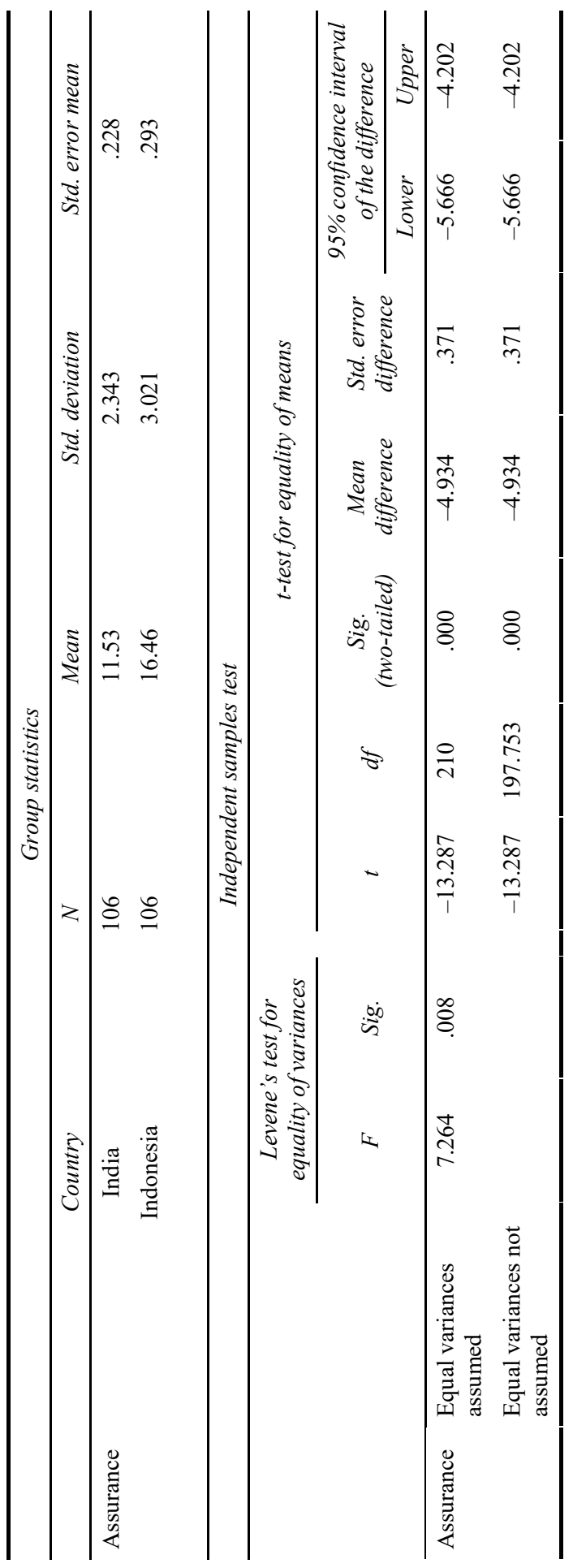


Table 13 Independent samples T-test result - empathy

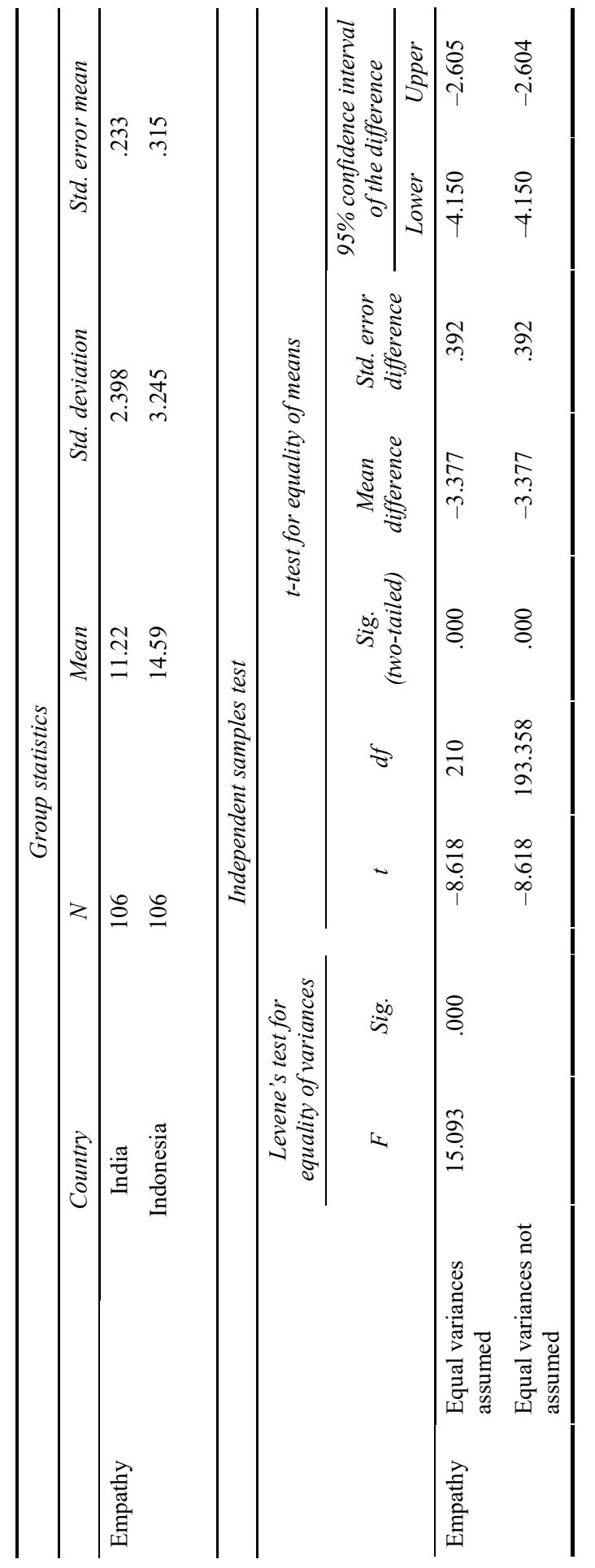




\section{Tangibles}

Tangibles variable test results show that consumer ratings in India and Indonesia on tangibles (physical ability) are not different or equal, by the result of $t$ value $-0.977<$ 1.983 and value of sig. $0.330>0.05$, as shown in Table 9 .

\section{Reliability}

Reliability variable test results show that consumer ratings in India and Indonesia on reliability are not different or equal, by the result of $t$ value $-0.095<1.983$ and value of sig. $0.924>0.05$, as shown in Table 10 .

\section{Responsiveness}

Responsiveness variable test results show that consumer ratings in India and Indonesia on responsiveness are not different or equal, by the result of $t$ value $-1.217<1.983$ and value of sig. $0.225>0.05$, as shown in Table 11 .

\section{Assurance}

Assurance variable test results show that consumer ratings in India and Indonesia on assurance are different or not equal, by the result of $t$ value $-13.287>1.983$ and value of sig. $0.000<0.05$, as shown in Table 12 .

\section{Empathy}

Empathy variable test results show that consumer ratings in India and Indonesia on empathy are different or not equal, by the result of $t$ value $-13.287>1.983$ and value of sig. $0.000<0.05$, as shown in Table 13 .

\subsection{Discussion}

From the results of the regression that has been described in the research results, there are several things that can be discussed to be known further. The results showed that from the five service quality variables given to respondents in India and Indonesia gave the same result that only responsiveness, assurance and empathy variables affect on customer satisfaction while tangibles and reliability variables did not affect on customer satisfaction.

The results of this study indicate that consumers of online music products both in India and Indonesia argue that online music sites that are able to provide good quality and ability to provide information needed by consumers will affect on consumer satisfaction, in addition to online music sites are also able to provide attention to consumers by giving recommendations of songs that are popular or the type of song preferred by consumers based on consumer habits in listening to music. Consumers also argue that online music sites are able to provide a quick response to consumers when consumers have problems in using it.

But consumers think that online music sites are still not user friendly so that consumers sometimes find it difficult in using it, so sometimes for new consumers first 
use it must first learn the site to be able to get the song as desired, and sometimes consumers feel disappointed because the results obtained did not match with which has been promoted about the online music site.

This result is in line with previous research by Ali and Sankaran (2010) which states that the customers are satisfied with the online method of shopping because it makes it easy for consumers, and previous research (Utami, 2013) research result states that there is a positive and significant relationship between quality of service to customer satisfaction. This result is also in line with previous research (Archakova, 2013) which states that the bigger amounts of respondents are quite satisfied with the service quality in the market. Service quality satisfaction level includes product quality, employees' effectiveness and service expectation in total, and in general, it means that on $60 \%$ of customers are satisfied with the quality level.

A different test is also done in this research to know whether or not the difference of consumer perception which come from two countries that is India and Indonesia. Different test results show that the variables of tangibles, reliability and responsiveness are the same while assurance and empathy variables show different results from both countries. This means that consumers from India and Indonesia both argue that online music sites sometimes do not facilitate them in finding the desired song so that consumers sometimes feel disappointed with the results obtained, although consumers from India and Indonesia argue that online music sites can provide service and complete information. Consumer opinions differ from both countries in terms of quality of music products from online music sites and the attention given by online music sites to consumers who visit their sites. The availability of this music website allows consumers to buy and enjoy music online. The availability of this music website allows consumers to buy and enjoy music online, and also makes it easy for consumers to choose the type of transaction and consumer preferences while selecting m-wallet for payment (Saurabh and Kumar, 2018).

\section{Conclusions}

The simultaneous test results for respondents in Indonesia and India show that service quality affects on customer satisfaction of music product website. Partial test results for respondents in Indonesia and India indicate that the variables of responsiveness, assurance, and empathy affect on customer satisfaction of music product website. Different test results state that the tangibles, reliability and responsiveness variables do not differ from the two countries, while the assurance, empathy and customer satisfaction have a different for both countries.

The results of this study may provide information to the music industry, with this research, the perpetrators of music involved in producing works of art of music and the company involved in selling the music, to be able to pay more attention and improve things that can attract consumer intentions to buy music products. Hopefully, by the results of this study, the music industry will further improve music product quality to produce a sound that is clear and crisp, providing ease and smoothness for consumers to obtain music products, so as to make the music industry to bounce back and preferred by consumers.

The results of this study can provide information to the music industry, and musicians involved in producing musical artworks and companies involved in selling music, to be 
able to give more attention to consumers, so as to improve the quality of music that can provide satisfaction to customers. Hopefully, with the results of this study, the music industry will further improve the quality of music products to be able to provide satisfaction to customers, and it is expected that consumers will be more loyal in consuming music products.

\section{References}

Ajzen, I. (1991) 'The theory of planned behavior', Organizational Behavior and Human Decision Process, Vol. 50, pp.179-211, https://doi.org/10.1016/0749-5978(91)90020-T.

Ali, P. and Sankaran, S. (2010) 'Online Shopping' Customer Satisfaction and Loyalty in Norway, Master's thesis in Business Administration, MBA programme, Blekinge Teknisa, Högskola.

Archakova, A. (2013) Service Quality and Customer Satisfaction. Case study: Company X, Thesis, Saimaa University of Applied Sciences, Faculty of Business Administration, Lappeenranta.

Arikunto, S. (2010) Manajemen Penelitian, PT Rineka Cipta, Jakarta.

Cooper, D.R. and Emory, C.W. (1996) Business Research Method, Richard Irwin Inc., USA.

Grönroos, C. (2005) Service Management and Marketing. A Customer Relationship Management Approach, Swedish School of Economics and Business Administration, John Wiley and Sons, Ltd., Hoboken.

Gupta, P. (2014) Comparative Study of Online and Offline Shopping: A Case Study of Rourkela in Odisha, Thesis, National Institute of Technology, Odisha, India.

Hadi, S. (1986) Metodologi Research, Libety, UGM, Yogyakarta.

Kotler, P. (1997) Manajemen Pemasaran Analisis Perencanaan Implementasi dan Kontrol, Jilid 1, PT, Prehalindo, Jakarta.

Kotler, P. and Armstrong, G. (2008) Principles of Marketing, 12th ed., Prentice Hall, Inc. A Pearson Education Company, Upper Saddle River, New Jersey.

Kumar, V. and Pradhan, P. (2016) 'Reputation management through online feedbacks in e-business environment', International Journal of Enterprise Information Systems (IJEIS), January-March, Vol. 12, No. 1, pp.21-37 (IGI Global Publication).

Lovelock, C. and Wirtz, J. (2011) Services Marketing: People, Technology, Strategy, Prentice Hall, Inc. Pearson Education Limited, England.

Priyanto, D. (2010) Teknik Mudah dan Cepat Melakukan Analisis Data Penelitian dengan SPSS, Gaya Media, Yogyakarta.

Purity, K.K. (2014) E-commerce and Performance of Online Business in Kenya, Thesis, School of Business, University of Nairobi [online] https://www.pdffiller.com/jsfiller-desk18/?projectId= 294686971\&expId=4946\&expBranch=1\#b65f7981 cb684ac7b50946cfc2bf3820.

Saurabh and Kumar, V. (2018) 'Adoption of mobile wallets in India: an analysis. Technology Integration for the success of B2C M-commerce in India: opportunities and challenges', IUP Journal of Information Technology, January-March, Vol. 14, No. 1, pp.42-57.

Sekaran, U. and Bougie, R. (2016) Research Methods for Business: A Skill Building Approach, 7th ed., John Wiley \& Sons Ltd., Chichester, West Sussex, UK.

St. Amour, L. (2012) The Internet: An Unprecedented and Unparalleled Platform for Innovation and Change, The Global Innovation Index, pp.157-162, Confederation of Indian Industry, INSEAD by ThoughtSpring Concultancy Private Ltd.

Utami, S.B. (2013) Pengaruh Kualitas Pelayanan Dan Kinerja Karyawan Terhadap Kepuasan Nasabah Pada PT, Taspen (Persero) Cabang Yogyakarta, Universitas Negeri Yogyakarta.

Zeithaml, V.A., Bitner, M.O. and Gremler, D.E. (2009) Service Marketing: Integrating Customer Focus Across the Firm, McGraw-Hill/Irwin, New York, NY. 